\title{
Acre USA Survey
}

National Cancer Institute

\section{Source}

National Cancer Institute. Acre USA Survey. NCI Thesaurus. Code C68868.

A unit of area equal to 4046.87261 square meters. The unit is based on the USA survey foot of $1200 / 3937$ meters. 